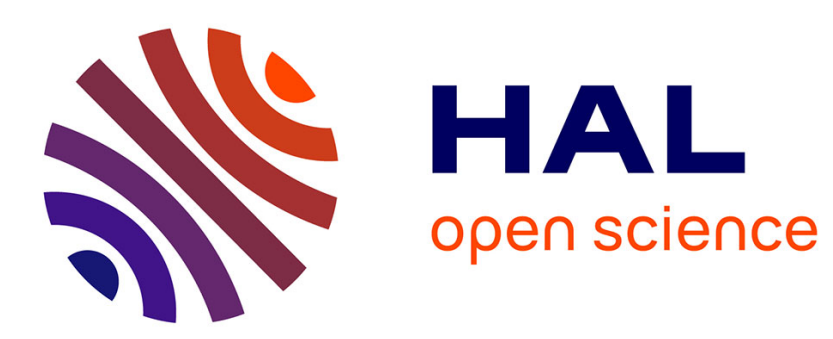

\title{
Radiation use efficiency, chlorophyll fluorescence, and reflectance indices associated with ontogenic changes in water-limited Chenopodium quinoa leaves
}

T. Winkel, M Methy, F Thenot

\section{- To cite this version:}

T. Winkel, M Methy, F Thenot. Radiation use efficiency, chlorophyll fluorescence, and reflectance indices associated with ontogenic changes in water-limited Chenopodium quinoa leaves. Photosynthetica, 2002, 40 (2), pp.227-232. 10.1023/A:1021345724248 . ird-03373214

\author{
HAL Id: ird-03373214 \\ https://hal.ird.fr/ird-03373214
}

Submitted on 11 Oct 2021

HAL is a multi-disciplinary open access archive for the deposit and dissemination of scientific research documents, whether they are published or not. The documents may come from teaching and research institutions in France or abroad, or from public or private research centers.
L'archive ouverte pluridisciplinaire HAL, est destinée au dépôt et à la diffusion de documents scientifiques de niveau recherche, publiés ou non, émanant des établissements d'enseignement et de recherche français ou étrangers, des laboratoires publics ou privés. 


\title{
Radiation use efficiency, chlorophyll fluorescence, and reflectance indices associated with ontogenic changes in water-limited Chenopodium quinoa leaves
}

\author{
T. WINKEL ${ }^{*}$, M. MÉTHY ${ }^{* * * * *}$, and F. THÉNOT ${ }^{* *}$ \\ UR Climat et Fonctionnement des Agroécosystèmes, IRD, CP 9214, La Paz, Bolivia* \\ Centre d'Écologie Fonctionnelle et Evolutive, CNRS, F-34293 Montpellier Cedex 5, France**
}

\begin{abstract}
Net photosynthetic rate, radiation use efficiency, chlorophyll (Chl) fluorescence, photochemical reflectance index (PRI), and leaf water potential were measured during a 25-d period of progressive water deficit in quinoa plants grown in a glasshouse in order to examine effects of water stress and ontogeny. All physiological parameters except $F_{\mathrm{v}} / F_{m}$ were sensitive to water stress. Ontogenic variations did not exist in $\mathrm{F}_{\mathrm{v}} / \mathrm{F}_{\mathrm{m}}$ and leaf water potential, and were moderate to high in the other parameters. The complete recovery of photosynthetic parameters after re-irrigation was related with the stability in $F_{\mathrm{v}} / \mathrm{F}_{\mathrm{m}}$. PRI showed significant correlation with predawn leaf water potential, $\mathrm{F}_{\mathrm{m}}$, and midday $\mathrm{F}_{\mathrm{y}} / \mathrm{F}_{\mathrm{m}}$. Thus $\mathrm{PRI}$ and $\mathrm{Chl}$ fluorescence may help in assessing physiological changes in quinoa plants across different developmental stages and water status.
\end{abstract}

Additional key words: leaf water potential; net photosynthetic rate; PRI; quinoa; water stress.

\section{Introduction}

Non-invasive techniques such as $\mathrm{Chl}$ fluorescence and photochemical reflectance index (PRI) techniques have been developed in early 1980 s and late 1980 s, respectively, to detect changes in plant physiological status. In comparison with conventional ecophysiological methods such as measurements of net photosynthetic rate $\left(P_{\mathrm{N}}\right)$ or leaf water content, these methods are more informative with respect to localising photosynthetic apparatus disturbances (Méthy et al. 1991, 1996, Lichtenthaler 1996, Gamon et al. 1997). They also offer the potential for remote applications at scales larger than the leaf (Peñuelas and Filella 1998). Both techniques are related to the mechanisms of dissipation of excess energy in stressed plants that receive more photons than can be used for carbon assimilation. One of these mechanisms consists in the re-radiation of the excess energy as fluorescence emitted by $\mathrm{Chl} a$ of photosystem 2 (PS2) (Krause and Weis 1991). The other mechanism is heat dissipation, linked to the inter-conversion of the xantho- phyll cycle pigments, and inducing changes in the leaf reflectance at $531 \mathrm{~nm}$ which are detected by PRI (Peñuelas et al. 1995, Gamon et al. 1997).

The effects of water stress on Chl fluorescence, PRI, and their relations with radiation use efficiency have been widely reported, but sometimes with scattered or contradictory result (Peñuelas et al. 1994, 1997). Ontogenic effects could explain part of these results, since photosynthetic processes underlying these eco-physiological techniques are sensitive not only to environmental stresses, but also to normal ontogenetic changes. Studies on herbaceaous as well as perennial species show that changes in Chl fluorescence related to ontogeny can be larger than those induced by any stress factor or genotypic difference (Krebs et al. 1996, Šesták and Siffel 1997, Synková et al. 1997, Araus et al. 1998, Gielen et al. 2000). The same kind of reasoning can be held for PRI where additional confounding influences (vegetation structure, calibration errors) can impact a relatively small

Received 3 January 2002, accepted 4 June 2002.

\footnotetext{
*** Corresponding author, fax: (+33)(0)4 674121 38; e-mail: maurice.methy@cefe.cnrs-mop.fr Abbreviations: Chl - chlorophyll; DAE - days after emergence; $\mathrm{F}_{\mathrm{m}}$ - maximal fluorescence in the dark-adapted state; $\mathrm{F}_{\mathrm{rm}}{ }^{\prime}-\mathrm{maximal}$ fluorescence in the light-adapted state; $F_{0}$ - initial fluorescence; $F_{s}$ - steady state value of fluorescence; $F_{\mathrm{v}} / F_{m}-$ photochemical efficiency of dark-adapted leaves; $\Delta \mathrm{F} / \mathrm{F}_{\mathrm{m}}$ ' - photochemical efficiency of photosystem $2 ; P_{\mathrm{N}}$ - net photosynthetic rate; PPFD - photosynthetic photon fluence density; PRI - photochemical reflectance index; PRUE - photosynthetic radiation use efficiency; PS - photosystem; $\mathrm{R}_{\mathrm{x}}$-reflectance at $\mathrm{x} \mathrm{nm}$.

Acknowledgements: We thank A. Bonifacio (PROINPA, Bolivia) for providing the quinoa seeds, C. Collin and his staff for excellent technical assistance, and two anonymous reviewers for comments on the manuscript.
} 
signal (Gamon and Qiu 1999, Aparicio et al. 2000). It is thus essential to better understand the normal seasonal changes in $\mathrm{Chl}$ fluorescence and PRI to avoid interpreting them as indicative of stress damage when, in fact, they are normal part of the seasonal physiological cycle (Mohammed et al. 1995).

Chenopodium quinoa (Willd.) is a herbaceaous, annual crop originated in the Andes, well-adapted to harsh environments characterised by drought, frost, soil salinity, and high solar visible and UV-B radiation (Tapia et al. 1979). It shows particular leaf properties such as epidermal vesicles (bladder cells), highly varying contents of leaf pigments, and high nitrogen concentration.

\section{Materials and methods}

Plants, growth conditions, and stress treatment: The experiment was carried out in a greenhouse at the CefeCNRS, Montpellier, France $\left(43^{\circ} 36^{\prime} \mathrm{N}, 3^{\circ} 53^{\prime} \mathrm{E}\right)$. C. quinoa cv. Sajama was grown on a mixture of compost and sandy soil in $2000 \mathrm{~cm}^{3}$ pots, at a density of one plant per pot and 36 pots per square meter. Pots were moved randomly every other day to avoid position effects. Sewing was on 27 January 2000, and emergence was on 31 January. Plants were irrigated with a complete nutritive solution (nitrogen $0.19 \mathrm{~g} \mathrm{~m}^{-3}$, phosphorus $0.1 \mathrm{~g} \mathrm{~m}^{-3}$, potassium $0.18 \mathrm{~g} \mathrm{~m}^{-3}$ ). Irrigation was applied daily at a dose equal to the average evapotranspiration calculated by weighing eight control pots daily. Stress treatment was applied progressively on half of the plants, reducing the irrigation in comparison to the control by $50 \%$ from 46 to $52 \mathrm{~d}$ after emergence (DAE), by $66 \%$ from 53 to 54 $\mathrm{DAE}$, and by $75 \%$ from 55 to $58 \mathrm{DAE}$. From $59 \mathrm{DAE}$ on, full irrigation was again applied to all the plants to study stress recovery in re-irrigated plants. The experiment was over at $69 \mathrm{DAE}$.

Physiological measurements: Chl fluorescence, PRI, and photosynthesis parameters were measured on the adaxial surface of four top-canopy, fully expanded leaves randomly selected on four plants in each water treatment. Leaf water potential was measured at predawn and at noon, on similar leaves with three replicates in each water treatment: Due to technical constraints, data collection for the various parameters could not be made on the same day, but was made over two consecutive days during the stress period, and three to six days during the recovering period.

Chl fluorescence was measured with a $P A M-2000$ fluorometer ( $H$. Walz, Germany) using the saturation pulse method (Schreiber et al. 1986, Schreiber and Bilger 1987). Initial Chl fluorescence, $F_{0}$, was induced by applying a weak modulated measuring radiation $(0.1 \mu \mathrm{mol}$ $\mathrm{m}^{-2} \mathrm{~s}^{-1}, 655 \mathrm{~nm}$ ) at a frequency of $600 \mathrm{~Hz}$ on the adaxial surface of dark-adapted leaves. Using red excitation radiation allows to minimise the absorption by the photosynthetic accessory pigments of the pigment antenna
These leaf properties present large genotypic and ontogenetic variations, but their functional role remains largely unknown (Jacobsen and Mujica Sánchez 1999). Chl fluorescence and PRI techniques would then help the rapid and non-invasive assessment of functional heterogeneity within and among quinoa populations. Prior to this, information is needed on the performance of these techniques in assessing physiological and ontogenic changes in the particular case of $C$. quinoa. Thus, the aim of this study was to analyse the variations in Chl fluorescence, PRI, $P_{\mathrm{N}}$, and leaf water potential in quinoa plants during a 25 -d period of progressive water deficit and recovering at the pre-flowering and anthesis stages.

(Chl $a$, Chl $b$, carotenoids) and reaches deeper cell and chloroplast layers inside the leaf than shorter wavelengths (Rinderle and Lichtenthaler 1988). Leaf clips ( $P E A / L C$, Hansatech, UK) were used for the dark adaptation ( $30 \mathrm{~min}$ ) of the samples. The $\mathrm{F}_{0}$ level is $\mathrm{Chl}$ fluorescence when all reaction centres are open, and the rate of PS2 photochemistry is not limited. It may increase if the PS2 reaction centres are damaged, or if the transfer of excitation energy from the antenna to the reaction centres is impeded. Maximum Chl fluorescence in the dark-adapted stage $\left(F_{m}\right)$ was determined using an $800 \mathrm{~ms}$ pulse of high irradiance "white light" $\left(12000 \mu \mathrm{mol} \mathrm{m} \mathrm{m}^{-2} \mathrm{~s}^{-1},<710 \mathrm{~nm}\right)$. The steady-state value of fluorescence $F_{s}$ was measured, and a second pulse of high irradiance white light was used to determine maximum $\mathrm{Chl}$ fluorescence in the light-adapted phase $\left(\mathrm{F}_{\mathrm{m}}\right)$. The photochemical efficiencies of PS2 in the dark (maximum PS2 photochemical efficiency) and in the light (effective quantum yield of PS2) were calculated according to Genty et al. (1989):

$$
\begin{aligned}
& F_{v} / F_{m}=\left(F_{m}-F_{0}\right) / F_{m} \\
& \Delta F / F_{m}{ }^{\prime}=\left(F_{m}^{\prime}-F_{s}\right) / F_{m}{ }^{\prime}
\end{aligned}
$$

$F_{\mathrm{v}} / \mathrm{F}_{\mathrm{m}}$ was measured predawn and at midday. $\Delta F / F_{m}{ }^{\prime}$ was measured during the day at photosynthetic photon flux densities (PPFD) higher than $1600 \mu \mathrm{mol} \mathrm{m}{ }^{-2} \mathrm{~s}^{-1}$.

PRI was measured using a two-channel fiber optic radiometer (SKR 116/SKP 120, Sky Instrument, UK) equipped with interference optic filters transmitting the 530 and $570 \mathrm{~nm}$ wavelengths with a bandwidth of $10 \pm 2 \mathrm{~nm}$. Reflectance spectra were calculated by dividing the spectral radiance of the adaxial surface of the leaf by the radiance of a $99 \%$ reflective white standard (Spectralon, Labsphere, USA). PRI was formulated following Peñuelas et al. (1995):

$$
\mathrm{PRI}=\left(\mathrm{R}_{530}-\mathrm{R}_{570}\right) /\left(\mathrm{R}_{530}+\mathrm{R}_{570}\right)
$$

where $R_{530}$ indicates reflectance at $530 \mathrm{~nm}$ (due to the availability of interference filters, this waveband was used in place of $531 \mathrm{~nm}$, the waveband of the "xanthophyll signal") and $R_{570}$ indicates reflectance at $570 \mathrm{~nm}$ (a reference waveband). By referencing $R_{530}$ against $R_{570}$, 
this index partly reduces the effect of other factors besides the xanthophyll cycle, such as chloroplast movements, that can affect reflectance in this spectral region (Gamon et al. 1997). PRI was measured during the day at PPFD higher than $1600 \mu \mathrm{mol} \mathrm{m}^{-2} \mathrm{~s}^{-1}$.

$P_{\mathrm{N}}$ was measured with a portable photosynthesis system (LI-6400, Li-Cor, USA). Air temperature and humidity in the cuvette varied between 18 and $24^{\circ} \mathrm{C}$, and 16 and $50 \%$, respectively, while input air $\mathrm{CO}_{2}$ concentration was between 325 and $392 \mu \mathrm{mol} \mathrm{mol} \mathrm{m}^{-1}$. Irradiance-response curves were registered within $40 \mathrm{~min}$ in the range $0-1000 \mu \mathrm{mol} \mathrm{m} \mathrm{m}^{-2} \mathrm{~s}^{-1}$ PPFD, and within $15 \mathrm{~min}$ in the range $1000-1870 \mu \mathrm{mol} \mathrm{m} \mathrm{m}^{-2} \mathrm{~s}^{-1}$ PPFD. Values corresponding to PPFD between 1775 and $1870 \mu \mathrm{mol} \mathrm{m}^{-2} \mathrm{~s}^{-1}$ were used to estimate the photon-saturated $P_{\mathrm{N}}$ $\left[\mu \mathrm{mol}\left(\mathrm{CO}_{2}\right) \mathrm{m}^{-2} \mathrm{~s}^{-1}\right]$ and the instantaneous photosynthetic

\section{Results}

Kinetics: In control plants, predawn leaf water potential varied little during the experiment (mean value of -0.45 $\mathrm{MPa} \pm 11 \%$, Fig. $1 A$ ), and minimum leaf water potential remained between -0.6 and $-1.07 \mathrm{MPa}$ (Fig. 1B). In stressed plants, the progressive reduction of irrigation induced a fall in predawn leaf water potential statistically significant after $12 \mathrm{~d}$, and reaching $-0.97 \mathrm{MPa}$ after $14 \mathrm{~d}$. The effect of water stress was more rapid on the minimum leaf water potential, statistically lower than the control since the $10^{\text {th }} \mathrm{d}$ of deficit. Minimum leaf water potential reached $-1.38 \mathrm{MPa}$ after $12 \mathrm{~d}$ of water deficit. Then, two days of re-irrigation were enough for the complete recovering of water status in formerly stressed plants.

PRUE in control plants (Fig. 1C) was stable at the beginning of the experiment [mean value of the first 3 observations $\left.=10.7 \mathrm{mmol}\left(\mathrm{CO}_{2}\right) \mathrm{mol}^{-1}(\mathrm{PPFD}) \pm 5 \%\right]$, then it decreased by $30 \%$ by the end of the period (significant difference, $p<0.001$ ). In stressed plants, PRUE remained similar to that of control plants in a first period (53 DAE), but after $13 \mathrm{~d}$ of irrigation deficit water stress induced a significant drop in $P_{\mathrm{N}}(-84 \%$ relative to the control $)$. In these stressed plants, re-irrigation allowed for the complete recovering of PRUE, which even appeared statistically higher than in control plants by the end of the experiment (69 DAE). $P_{\mathrm{N}}$ showed essentially the same variations as PRUE (values not shown), since the range of PPFD was narrow, and was highly correlated with stomatal conductance $(r=0.92, n=28)$. $P_{\mathrm{N}}$ continued to increase up to PPFD of $1870 \mu \mathrm{mol} \mathrm{m} \mathrm{m}^{-2}$, indicating that photoinhibition did not occur at the irradiances used in this experiment.

PRI in control plants increased regularly with time, from -0.07 to -0.02 between 46 and $69 \mathrm{DAE}$ (Fig. 1D). The same trend was observed on stressed plants, yet with an increase higher than in the control plants by the end of radiation use efficiency, PRUE $\left[\mathrm{mmol}\left(\mathrm{CO}_{2}\right) \mathrm{mol}^{-1}\right.$ (PPFD)].

As an index of plant water stress, leaf water potential was measured predawn, $\Psi_{\mathrm{p}}[\mathrm{MPa}]$ and near midday, $\Psi_{\mathrm{m}}$ [MPa] using a Scholander pressure chamber (PMS Instrument, USA).

Statistics: Means of control and stress treatments were compared using Student $t$-tests. Relations between PRI and the other physiological variables were analysed using Pearson correlation coefficients and linear regressions calculated from the four means of the control treatment corresponding to the four periods when measurements of the various parameters were coincident (on Fig. 2 these four periods are indicated in chronological order by $a, b$, $c$, and $d$ ).

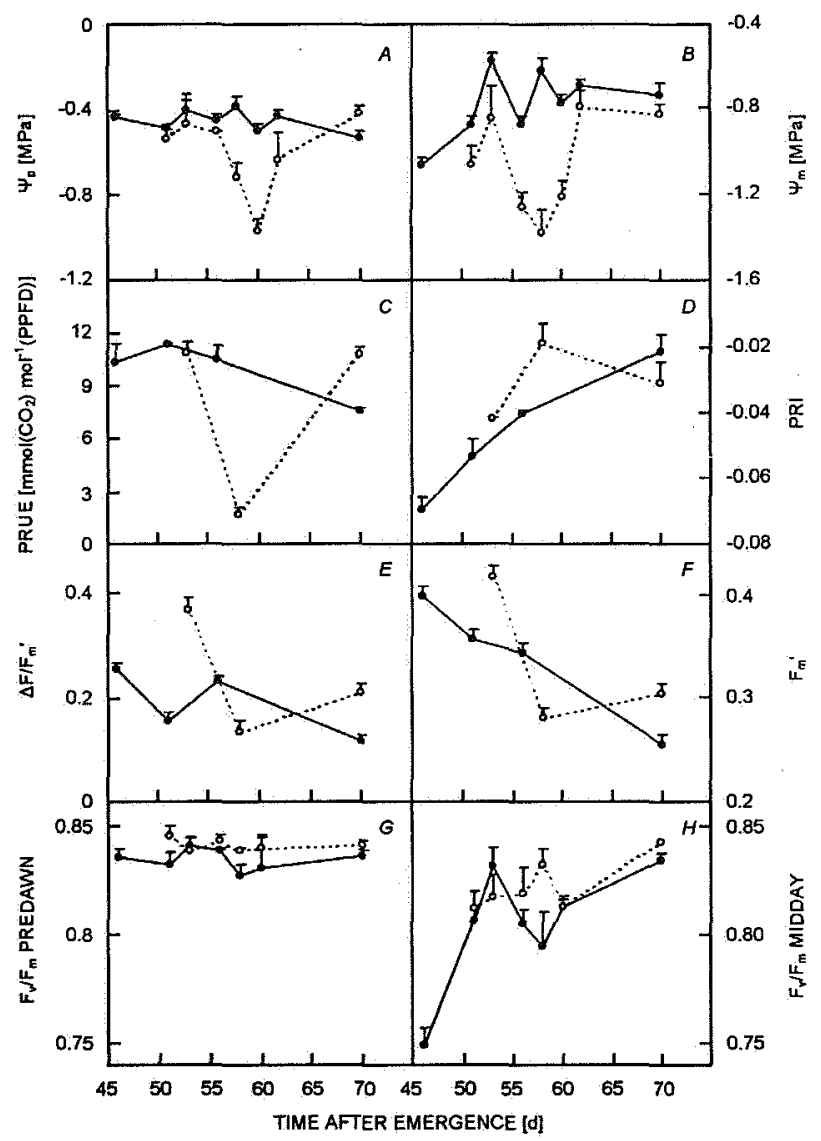

Fig. 1. Mean values of predawn $(A)$ and midday $(B)$ leaf water potential, photosynthetic radiation-use efficiency $(C)$, photochemical reflectance index $(D), \Delta \mathrm{F} / \mathrm{F}_{\mathrm{m}}{ }^{\prime}(E), \mathrm{F}_{\mathrm{m}}{ }^{\prime}(F)$, predawn $(G)$ and midday $(H) \mathrm{F}_{\mathrm{v}} / \mathrm{F}_{\mathrm{m}}$ in control (closed symbols) and water stressed (open symbols) top-canopy, fully expanded quinoa leaves during plant ontogeny (vertical bars show one standard error). 

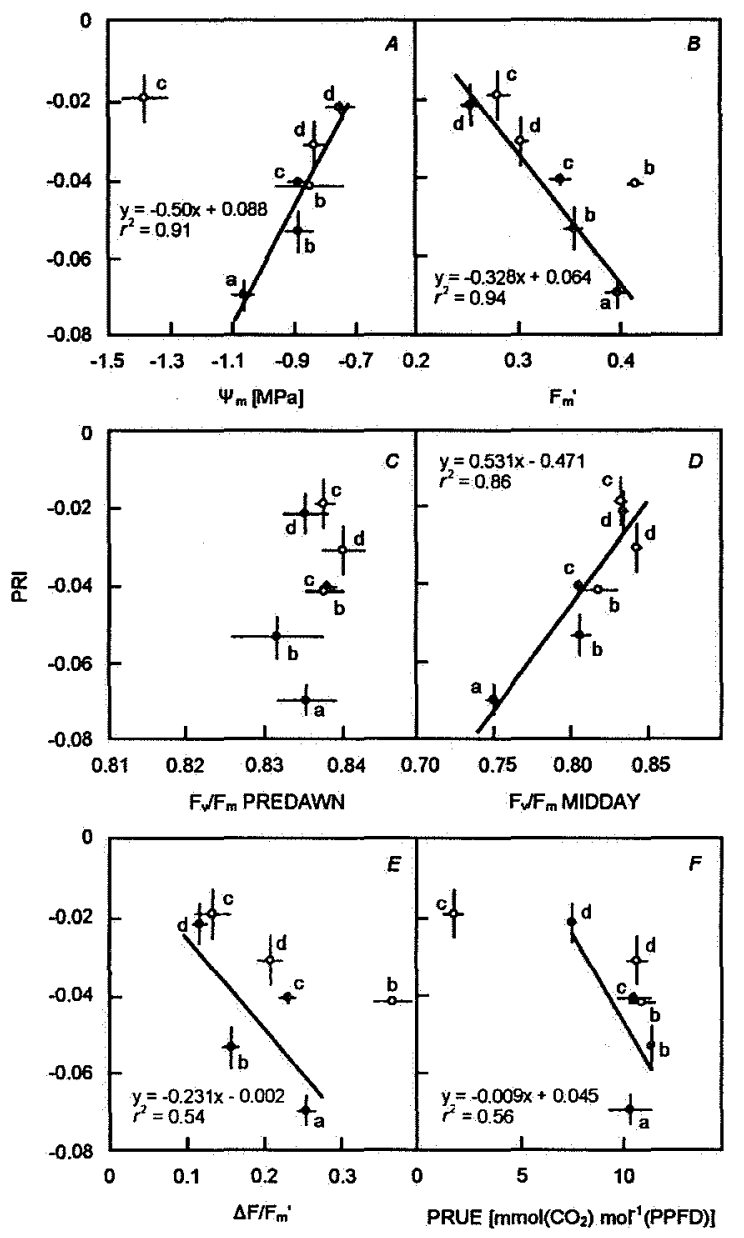

Fig. 2. Relations between photochemical reflectance index (PRI) and midday leaf water potential $(A), \mathrm{F}_{\mathrm{m}}{ }^{\prime}(B)$, predawn $\mathrm{F}_{\mathrm{v}} / \mathrm{F}_{\mathrm{m}}(C)$, midday $\mathrm{F}_{\mathrm{v}} / \mathrm{F}_{\mathrm{m}}(D), \Delta \mathrm{F} / \mathrm{F}_{\mathrm{m}}{ }^{\prime}(E)$, and photosynthetic radiation use efficiency, PRUE $(F)$ in control (closed symbols) and water stressed (open symbols) top-canopy, fully expanded quinoa leaves during plant ontogeny (vertical bars show one standard error, letters show successive time periods). Regressions were calculated for the control treatment $(n=4)$.

\section{Discussion}

Effects of water deficit versus ontogenic effects: Although progressive, the water deficit had a pronounced effect on leaf water potential, $P_{\mathrm{N}}$, and radiation-use efficiency. This stress effect appeared more rapidly in minimum leaf water potential than in the other physiological parameters. But in all cases, the effect of water deficit was reversible, and few days of re-irrigation allowed for the complete recovering of the leaf water status, $P_{\mathrm{N}}$, and radiation-use efficiency. Rasmussen (1997) also observed this fast recovery after a drought stress period. It is consistent with the stability in predawn $F_{v} / F_{m}$, indicative of the maintenance of a high photo-chemical efficiency in the dark phase despite the water deficit. The level of water stress reached in this experiment $(-1.4 \mathrm{MPa})$ was comparable to that observed at the pre-flowering and

flowering stages in quinoa plants grown in pots (Jensen et al. 2000). But it appeared much less severe than that observed on quinoa plants subjected to post-flowering drought in the Bolivian Altiplano (Vacher 1998). The difference could be due to the greater intensity of water deficit combined with higher evaporative demand of the atmosphere in the conditions of Altiplano. But it could also be explained by the difference in the development stage (maturity in the cited study, pre-flowering and anthesis in our case), as leaf water potential tends to decline rapidly in senescing plants (Karamanos and Papatheohari 1999, Mastrorilli et al. 1999). In our experiment limited to the pre-flowering and anthesis phase, water status parameters in control plants remained stable and did not show ontogenic variations, while $P_{\mathrm{N}}$ and PRUE, stable in 
the first two weeks of the experiment, declined significantly by the end of the period. This trend is in agreement with the observations of Jensen et al. (2000) on changes in $P_{\mathrm{N}}$ during the flowering and grain filling phases. It corresponds to the decrease in radiation-use efficiency observed in other species during late ontogeny (Hodáňová 1981, Scartazza et al. 1998, Reynolds et al. 2000) and coincides with decreases in $F_{m}{ }^{\prime}$ and $\Delta F / F_{m}{ }^{\prime}$ indicative of lower photo-chemical efficiency in the light phase by the end of the period.

On the other hand, ontogenic variations were clear and consistent in PRI, $F_{m}^{\prime}$, and $\Delta F / F_{m}{ }^{\prime}$. During the four weeks of experiment, and in the absence of water stress (control plants), PRI increased by $70 \%$, while $\mathrm{F}_{\mathrm{m}}{ }^{\prime}$ and $\Delta \mathrm{F} / \mathrm{F}_{\mathrm{m}}{ }^{\prime}$ dropped by 36 and $55 \%$, respectively. On the opposite, the impact of the water deficit on PRI and the Chl fluorescence parameters was nil (case of $F_{\mathrm{v}} / \mathrm{F}_{\mathrm{m}}$ ) or without any clear pattern (case of $\mathrm{PRI}, \Delta \mathrm{F} / \mathrm{F}_{\mathrm{m}}{ }^{\prime}$, and $\mathrm{F}_{\mathrm{m}}{ }^{\prime}$ ). Regarding PRI, by the end of the water deficit period the stressed plants showed values not only higher by $50 \%$ but also much more variable (CV $=56 \%$ ) than the control. Due to this variability, PRI in stressed plants did not appear statistically larger than in the control. Such variability in PRI could reflect functional heterogeneity in quinoa plants under stress. In the particular case of $\Delta \mathrm{F} / \mathrm{F}_{\mathrm{m}}{ }^{\prime}$ and $\mathrm{F}_{\mathrm{m}}{ }^{\prime}$, the rapid variations observed in stressed plants may reveal changes in leaf optical properties, in relation to the alteration of the epidermal vesicles under the effect of water stress as observed by Adams et al. (1998) in Mesembryanthemum crystallinum.

Chl fluorescence and PRI as tools for drought stress assessment in $C$. quinoa: Our results showed consistent correlation, at leaf level, in dark-adapted state, between PRI and maximal photochemical efficiency of PS2 $\left(F_{v} / F_{m}\right)$. Application of water stress caused an increase in PRI in the light-adapted state, with negative correlation with PRUE and $\Delta F / F_{m}^{\prime}$. Similar results, unobservable with nutrient stress, were presented by Peñuelas et al. (1994) with water-stressed sunflower plants. However,

\section{References}

Adams, P., Nelson, D.E., Yamada, S., Chmara, W., Jensen, R.G., Bohnert, H.J., Griffiths, H.: Growth and development of Mesembryanthemum crystallinum (Aizoaceae). - New Phytol. 138: $171-190,1998$.

Aparicio, N., Villegas, D., Casadesus, J., Araus, J.L., Royo, C.: Spectral vegetation indices as nondestructive tools for determining durum wheat yield. - Agron. J. 92: 83-91, 2000.

Araus, J.L., Amaro, T., Voltas, J., Nakkoul, H., Nachit, M.M. Chlorophyll fluorescence as a selection criterion for grain yield in durum wheat under Mediterranean conditions. - Field Crops Res. 55: 209-223, 1998.

Cerovic, Z.G., Goulas, Y., Gorbunov, M., Briantais, J.M., Camenen, L., Moya, I.: Fluorosensing of water stress in plants: diurnal changes of the mean lifetime and yield of chlorophyll fluorescence, measured simultaneously and at distance with a t-LIDAR and a modified PAM-fluorimeter, in maize, most of the correlation between PRI and $F_{v} / F_{m}$ relies on ontogenetic changes during the three weeks of experimentation. A highly significant relationship also occurred between $P R I$ and $F_{m}$ '. This result was not expected since $F_{m}{ }^{\prime}$ is not normalised against any other Chl fluorescence parameter and should present high intrinsic variability. Santos et al. (1998) found $F_{m}$ ' highly correlated with the rate of electron transport through PS2 in infected cacao genotypes. Although $\mathrm{F}_{\mathrm{m}}{ }^{\prime}$ is often neglected as a parameter, these results suggest its interest in assessing the physiological status of plants across different genotypes, developmental stages, and environmental conditions.

Among other objectives, the present work aimed to test, by a case study, the use of Chl fluorescence and PRI signatures as tools for detection of water stress tolerance and stress-induced injuries. The above results confirm that $\mathrm{Chl}$ fluorescence induction, using the saturation pulse method associated to the pulse-amplitude-modulation technique, is a powerful tool, perfected for studying stress physiology and related photosynthetic processes at leaf level. However, non-imaging fiber-optic bundles average information over one to several square centimetres of leaf surface. Moreover, notwithstanding promising results (Günther et al. 1994, Cerovic et al. 1996), it is known that the Chl fluorescence standard techniques are still not always sufficiently suitable for remote sensing. Imaging fluorometers, laser-induced or flash-light induced fluorescence imaging systems (Lang et al. 1996, Sowinska et al. 1999, Lootens and Vandecasteele 2000) are particularly well-suited for the study of targets displaying heterogeneities in photosynthetic activities. Taking into account the particular leaf properties of C. quinoa, this patchiness needs to be further investigated. PRI is suited for remote study of photosynthetic function, and promising results were obtained at the leaf and canopy levels (Peñuelas et al. 1995, Aparicio et al. 2000, Nichol et al. 2000). However, emphasis was laid on canopy structure induced problems (Gamon and Qiu 1999, Méthy 2000). These behaviours of PRI need also to be further investigated.

sugar beet, and kalanchoë. - Remote Sens. Environ. 58: 311 321, 1996.

Gamon, J.A., Qiu, H.-L.: Ecological applications of remote sensing at multiple scales. - In: Pugnaire, F.I., Valladares, F. (ed.): Handbook of Functional Plant Ecology. Pp. 805-846. Marcel Dekker, New York - Basel 1999.

Gamon, J.A., Serrano, L., Surfus, J.S.: The photochemical reflectance index: an optical indicator of photosynthetic radiation use efficiency across species, functional types, and nutrient levels. - Oecologia 112: 492-501, 1997.

Genty, B., Briantais, J.-M., Baker, N.R.: The relationship between the quantum yield of photosynthetic electron transport and quenching of chlorophyll fluorescence. - Biochim. biophys. Acta 990: 87-92, 1989.

Gielen, B., Jach, M.E., Ceulemans, R.: Effects of season, needle age, and elevated atmospheric $\mathrm{CO}_{2}$ on chlorophyll fluores- 
cence parameters and needle nitrogen concentration in Scots pine (Pinus sylvestris). - Photosynthetica 38: 13-21, 2000.

Günther, K.P., Dahn, H.G., Lüdeker, W.: Remote sensing of vegetation status by laser-induced fluorescence. - Remote Sens. Environ. 47: 10-17, 1994.

Hodáňová, D.: Photosynthetic capacitiy, irradiance and sequential senescence of sugar beet leaves. - Biol. Plant. 23: 58-67, 1981.

Jacobsen, S.E., Mujica Sánchez, A. (ed.): Primer curso internacional sobre fisiología de la resistencia a sequía en quinua (Chenopodium quinoa Willd.). [First international course on drought resistance physiology in quinoa (Chenopodium quinoa Willd.).] - Centro Internacional de la Papa, Lima 1999. [In Spanish]

Jensen, C.R., Jacobsen, S.-E., Andersen, M.N., Nuñez, N., Andersen, S.D., Rasmussen, L., Mogensen, V.O.: Leaf gas exchange and water relation characteristics of field quinoa (Chenopodium quinoa Willd.) during soil drying. - Eur. J. Agron. 13: 11-25, 2000.

Karamanos, A.J., Papatheohari, A.Y.: Assessment of drought resistance of crop genotypes by means of the water potential index. - Crop Sci. 39: 1792-1797, 1999.

Krause, G.H., Weis, E.: Chlorophyll fluorescence and photosynthesis: the basics. - Annu. Rev. Plant Physiol. Plant mol. Biol. 42: 313-349, 1991.

Krebs, D., Synková, H., Avratovšcuková, N., Kočová, M., Šesták, Z.: Chlorophyll fluorescence measurements for genetic analysis of maize cultivars. - Photosynthetica 32: 595-608, 1996.

Lang, M., Lichtenthaler, H.K., Sowinska, M., Heisel, F., Miehé, J.A.: Fluorescence imaging of water and temperature stress in plant leaves. - J. Plant Physiol. 148: 613-621, 1996.

Lichtenthaler, H.K.: Vegetation stress: an introduction to the stress concept in plants. - J. Plant Physiol. 148: 4-14, 1996.

Lootens, P., Vandecasteele, P.: A cheap chlorophyll $a$ fluorescence imaging system. - Photosynthetica 38: 53-56, 2000.

Mastrorilli, M., Katerji, N., Rana, G.: Productivity and water use efficiency of sweet sorghum as affected by soil water deficit occurring at different vegetative growth stages. - Eur. J. Agron. 11: 207-215, 1999.

Méthy, M.: Analysis of photosynthetic activity at the leaf and canopy levels from reflectance measurements: a case study. Photosynthetica 38: 505-512, 2000.

Méthy, M., Damesin, C., Rambal, S.: Drought and photosystem II activity in two Mediterranean oaks. - Ann. Sci. forest. 53: 255-262, 1996.

Méthy, M., Lacaze, B., Olioso, A.: Perspectives et limites de la fluorescence pour la télédétection de l'état hydrique d'un couvert végétal: cas d'une culture de soja. - Int. J. remote Sens. 12: 223-230, 1991.

Mohammed, G.H., Binder, W.D., Gillies, S.L.: Chlorophyll fluorescence: A review of its practical forestry applications and instrumentation. - Scand. J. Forest Res. 10: 383-410, 1995.

Nichol, C.J., Huemmrich, K.F., Black, T.A., Jarvis, P.G., Walthall, C.L., Grace, J., Hall, F.G.: Remote sensing of photosynthetic-light-use efficiency of boreal forest. - Agric. Forest Meteorol. 101: 131-142, 2000.

Peñuelas, J., Filella, I.: Visible and near-infrared reflectance techniques for diagnosing plant physiological status. - Trends Plant Sci. 3: 151-156, 1998.

Peñuelas, J., Filella, I., Gamon, J.A.: Assessment of photosynthetic radiation-use efficiency with spectral reflectance. -
New Phytol. 131: 291-296, 1995.

Peñuelas, J., Gamon, J.A., Fredeen, A.L., Merino, J., Field, C.B.: Reflectance indices associated with physiological changes in nitrogen- and water-limited sunflower leaves. Remote Sens. Environ. 48: 135-146, 1994.

Peñuelas, J., Llusia, J., Piñol, J., Filella, I.: Photochemical reflectance index and leaf photosynthetic radiation-use efficiency assessment in Mediterranean trees. - Int. J. Remote Sens. 18: 2863-2868, 1997.

Rasmussen, L.: Fotosyntese i quinoa (Chenopodium quinoa Willd.) i relation til vand og kvælstof. [Photosynthesis in Quinoa (Chenopodium quinoa Willd.) in Relation to Water and Nitrogen.] - M.Sc. Thesis, Copenhagen 1997. [In Danish.]

Reynolds, M.P., Delgado, M.I., Gutierrez-Rodriguez, M., Larque-Saavedra, A.: Photosynthesis of wheat in a warm, irrigated environment $-\mathrm{I}$ : Genetic diversity and crop productivity. - Field Crops Res. 66: 37-50, 2000.

Rinderle, U., Lichtenthaler, H.K.: The chlorophyll fluorescence ratio F690/F735 as a possible stress indicator. - In: Lichtenthaler, H.K. (ed.): Applications of Chlorophyll Fluorescence in Photosynthesis Research, Stress Physiology, Hydrobiology and Remote Sensing. Pp. 189-196. Kluwer Academic Publ., Dordrecht - Boston - London 1988.

Santos, I.C.F., De Almeida, A.-A.F., Valle, R.R.: Chlorophyll fluorescence parameters characterizing the development of two cacao genotypes infected by witches' broom. - Photosynthetica 35: 29-39, 1998.

Scartazza, A., Lauteri, M., Guido, M.C., Brugnoli, E.: Carbon isotope discrimination in leaf and stem sugars, water-use efficiency and mesophyll conductance during different developmental stages in rice subjected to drought. - Aust. J. Plant Physiol. 25: 489-498, 1998.

Schreiber, U., Bilger, W.: Rapid assessment of stress effects on plant leaves by chlorophyll fluorescence measurements. - In: Tenhunen, J.D., Catarino, F.M., Lange, O.L., Oechel, W.C. (ed.): Plant Response to Stress: Functional Analysis in Mediterranean Ecosystems. Pp. 27-53. Springer-Verlag, Berlin Heidelberg - New York - London - Paris - Tokyo 1987.

Schreiber, U., Schliwa, U., Bilger, W.: Continuous recording of photochemical and non-photochemical chlorophyll fluorescence quenching with a new type of modulation fluorometer. - Photosynth. Res. 10: 51-62, 1986.

Šesták, Z., Šiffel, P.: Leaf-age related differences in chlorophyll fluorescence. - Photosynthetica 33: 347-369, 1997.

Sowinska, M., Cunin, B., Deruyver, A., Heisel, F., Miehé, J.A., Langsdorf, G., Lichtenthaler, H.K.: Near-field measurements of vegetation by laser-induced fluorescence imaging. - In: Proc. EUROPTO Conference, Remote Sensing for Earth Science Ocean and Sea Ice Applications, Florence 20-24 Sept. 1999, Europto Series. SPIE 3868: 120-131, 1999.

Synková, H., Wilhelmová, N., Holá, D., Haisel, D., Šesták, Z.: Comparison of chlorophyll fluorescence kinetics and photochemical activities of isolated chloroplasts in genetic analysis of Lycopersicon esculentum Mill. hybrids. - Photosynthetica 34: 427-438, 1997.

Tapia, M., Gandarillas, H., Alandia, S., Cardozo, A., Mujica, A. (ed.): La quinua y la kañiwa, cultivos andinos. [Quinoa and Kaniwa, Andean Crops.] - CIID, Bogotá 1979. [In Spanish.]

Vacher, J.J.: Responses of two main Andean crops, quinoa (Chenopodium quinoa Willd) and papa amarga (Solanum juzepczukii Buk.) to drought on the Bolivian Altiplano: significance of local adaptation. - Agr. Ecosyst. Environ. 68: 99$108,1998$. 